\title{
Prediction of rye flour baking quality based on parameters of swelling curve
}

\author{
Sylwia Stępniewska ${ }^{1}$ Elżbieta Słowik ${ }^{1}$ - Grażyna Cacak-Pietrzak ${ }^{2} \cdot$ Daria Romankiewicz $^{2} \cdot$ Anna Szafrańska $^{1}$. \\ Dariusz Dziki ${ }^{3}$
}

Received: 14 August 2017 / Revised: 5 November 2017 / Accepted: 19 November 2017 / Published online: 1 December 2017

(c) The Author(s) 2017. This article is an open access publication

\begin{abstract}
The objective of this work was to use the swelling curve test for the evaluation of the baking value of rye flours commonly used for bread production. Ten rye flours obtained from industrial mills were used for investigations. The parameters characterized the flour properties such as protein content, ash content, pentosans content, falling number, amylograph peak viscosity and water absorption were determined. Besides, the swelling curve test and the baking test were performed. The results showed significant relations between flour properties and bread quality. Especially, all viscosity parameters obtained on the basis of swelling curve could be used for rye flour baking quality evaluation. Especially, the logarithmic decrease of viscosity was negatively correlated with crumb bread hardness after 1 and 4 days after baking $(r=-0.802$ and -0.789 , respectivietly). Besides, the breads with the lowest volume were obtained from flour with low amylograph peak viscosity and low logarithmic decrease of viscosity. In summary, the swelling curve test can be used as a useful tool for the evaluation of baking quality of rye flour.
\end{abstract}

Keywords Rye flour $\cdot$ Baking quality $\cdot$ Pentosans $\cdot$ Swelling curve $\cdot$ Bread

\section{Introduction}

Rye (Secale cereale L.) is in addition to wheat the major bread grain in Europe. Rye is mainly produced and consumed as bread in northern Europe; the major producers being Russia, Poland, Germany, Belarus and Ukraine. Rye bread is often made using sourdough, a process influencing both nutritional quality and taste of rye bread [1]. Starch is the most important constituent of rye flour which plays a major role in the crumb texture of rye bread. It is known, that baking properties of starch depend mostly on its swelling and gelatinization. Besides, starch, pentosans

Dariusz Dziki

dariusz.dziki@up.lublin.pl

1 Department of Grain Processing and Bakery, Prof. Wacław Dąbrowski Institute of Agricultural and Food Biotechnology, Rakowiecka 36, 02-532 Warsaw, Poland

2 Faculty of Food Science, Warsaw University of Life Sciences, Nowoursynowska 159C, 02-776 Warsaw, Poland

3 Department of Thermal Technology and Food Process Engineering, University of Life Sciences in Lublin, Doświadczalna 44, 20-280 Lublin, Poland and pentosans-degradation enzymes affect the baking value of rye flour [2]. Research carried out by Gräber [3] revealed that pentosans play mainly role in created properties of dough with temperature below $45{ }^{\circ} \mathrm{C}$ while starch is responsible for create crumb structure in temperature above $45{ }^{\circ} \mathrm{C}$. Pentosans are important component of rye flour. They bind water and contribute to the formation of viscous dough [4]. They are located mainly in outer parts of rye grain and divided into water extractable and water unextractable [5-7]. Low extraction flour is rich in starch and poor in pentosans content but has higher proportion water extractable pentosans in compared to high extraction flour. Rye flour with good baking value should be characterized by high pentosans content and also high proportion water extractable pentosans [8]. In bread making parts of water unextractable pentosans are converted in water extractable [9-11]. The hydrolysis of water unextractable pentosans changes their solubility and causes an increase dough viscosity and reduction of water binding capacity [12]. These changes caused an increase in bread volume and decrease crumb hardness [13, 14]. One method use to determined properties of dough association with pentosans content and activity cell wall degradation enzymes is the swelling curve 
test [15]. A lot of authors studied the swelling curve test, but mainly for wholemeal flours [16-18]. However there are no papers concerning possibility the use of swelling curve test for the evaluation of the baking quality of rye flour from milling industry. Therefore, the aim of this work was to evaluate the possibility using the swelling curve test for the evaluation of the baking value of rye flours commonly used for bread production.

\section{Materials and methods}

\section{Flour properties}

Ten rye flour samples (type 1400) obtained from different milling companies located in Poland were use for this study. The protein content (Nx625), ash content, the falling number and amylograph peak viscosity were determined according to ICC approved method no: 105/2, 104/1, 107/1 and 126/1, respectively [19]. For the evaluation degree of flour comminution the flour was separated with the held mechanical sifter using sieves with size $95 \mu \mathrm{m}$. Pentosans content was determined according to Hashimoto et al. [20]. Flours were evaluated for water absorption at $300 \mathrm{FU}$ with the Brabender farinograph on $50 \mathrm{~g}$ samples according to ICC 115/1 [19].

\section{Test swelling curve}

Test swelling curve test was performed according to Drews [21]. A slurry made from $120 \mathrm{~g}$ rye flour, $410 \mathrm{ml}$ water and $47 \mathrm{ml}$ sodium phosphate buffer solution $(\mathrm{pH}=5.0)$ was heated from $30{ }^{\circ} \mathrm{C}$ to $42{ }^{\circ} \mathrm{C}$ (heating rate $1.5^{\circ} \mathrm{C} / \mathrm{min}$ ) in a Viscograph (Brabender, Germany) bowl under constant stirring and held at $42{ }^{\circ} \mathrm{C}$ for $30 \mathrm{~min}$. The viscosity of the slurry was measured in Brabender unit (BU). A typical swelling curve was shown in Fig. 1. There are three parameters used for evaluation of the swelling curve. The first parameter (VA) represents initial viscosity at $30{ }^{\circ} \mathrm{C}$. The second parameter (VB) indicate viscosity after reaching

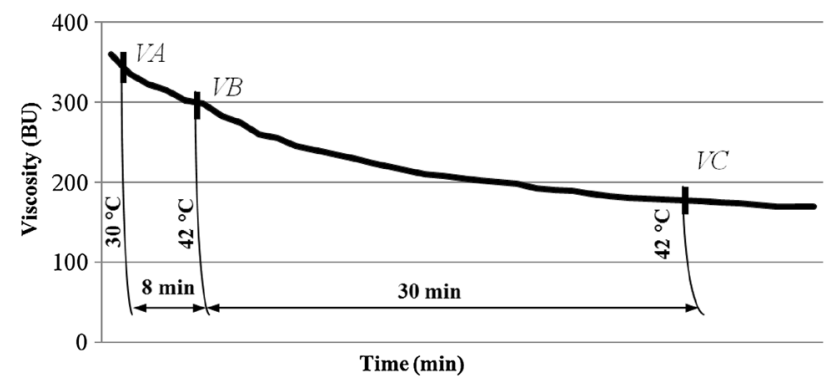

Fig. 1 The typical swelling curve; VA-initial viscosity at $30{ }^{\circ} \mathrm{C}$, VB-viscosity when the sample reaching $42{ }^{\circ} \mathrm{C}$, VC-final viscosity after holding suspension at $42^{\circ} \mathrm{C}$ for $30 \mathrm{~min}$ temperature $42{ }^{\circ} \mathrm{C}$. The third parameters (VC) indicate the final viscosity after holding suspension at $42{ }^{\circ} \mathrm{C}$ for $30 \mathrm{~min}$. The logaritmic decrease of vicosity VB and VC was also calculated $(\log \mathrm{VB}-\log \mathrm{VC})$. This parameter characterizes indirectly the intensity of enzymatic processes during the first phase of baking.

\section{Bread preparation}

High extraction rye pan breads were produced from rye flour samples in the laboratory baking trials. Breads were made with sourdough to reflect the usual production process utilized in Polish bakeries. The formulation used in the tests was given in Table 1 . The amount of water addition was adjusted to standard moisture of flour [14\% wet basis (wb)].

The dough was prepared with sourdough. A part flour from recipe was soured in a one-stage sourdough process. Sourdough procedure: $350 \mathrm{~g}$ of rye flour type 1400 was mixed with $3.5 \mathrm{~g}$ of starter (SAF Levain LV2 from Lesaffre) and with $525 \mathrm{~cm}^{3}$ of water $\left(35-36^{\circ} \mathrm{C}\right)$ to get homogeneous dough of soft consistency (yield 250) and temperature of about $30{ }^{\circ} \mathrm{C}$. Sourdough fermentation was performed in fermentation chamber for $16 \mathrm{~h}$ at $30{ }^{\circ} \mathrm{C}$ and $75 \%$ relative humidity. The final dough procedure was as fallow: the mature sourdough was combined with recipe's ingredients (Table 1) and water in amount corresponding to farinograph absorption ( $300 \mathrm{FU})$, decreased by the water contained in the sourdough. Dough kneading was performed using Turbomix-6,5 spiral mixer (HOMMEL) for $10 \mathrm{~min}$ on low speed. Desired dough temperature was $30-32{ }^{\circ} \mathrm{C}$. After a resting time of 10 min in fermentation cabinet dough was divided into five pieces of $350 \mathrm{~g}$ weight. The dough pieces were manually moulded, putted into the pans and proofed in fermentation cabinet at $35{ }^{\circ} \mathrm{C}$ and $75 \%$ relative humidity until they reached the normal level of proofing. The proofing time ranged from 20 to $25 \mathrm{~min}$. The end of proofing was signalised by the first cracks on the dough surface. The first phase of baking was performed at temperature $260{ }^{\circ} \mathrm{C}$ with steaming $(1 \mathrm{~min})$ at the beginning of the baking in the

Table 1 Used dough recipe

\begin{tabular}{ll}
\hline Ingredient & Weight $(\mathrm{g})$ \\
\hline Flour & $1000^{*}$ \\
Salt & 17 \\
Yeast & 10 \\
Starter culture LV2 & 3.5 \\
Water & Up to adequate \\
& consistency \\
\hline
\end{tabular}

\footnotetext{
*Moisture of flour (14\% wb)

${ }^{* *}$ The amount of added water was initially established for the consistency of dough equal $300 \mathrm{FU}$, during dough kneading if the dough was too dense the adequate correction of water was made
} 
decking oven (Piccolo, producer Wachtel, Germany). The temperature was decreased to $220{ }^{\circ} \mathrm{C}$ after 10 min of baking. The total time of baking was $40 \mathrm{~min}$. After baking the loaves were brushed with water, cooling and stored at ambient room temperature in polyethylene bags. The yield of dough (YD) was calculated on the basis of the total mass of dough $(a)$ and mass of using flour $(m)$ (14\% moisture wb) according to the equation:

$\mathrm{YD}=\frac{100 a}{m}(\%)$

The bread yield (YB), representing the amount of bread obtained from $100 \mathrm{~g}$ of flour, was calculated as follows:

$\mathrm{YB}=\frac{c \cdot \mathrm{YD}}{a}$,

where $a$ is a weight of dough portion before baking, $c$ is the mass of bread after cooling and YD is a dough yield.

\section{Bread properties}

Physico-chemical evaluation of obtained breads was carried out 1 day after baking. Additionally, the crumb bread hardness was measured also 4 days after baking in case of assay the changes of crumb texture during staling. The loaf volume was measured by rapeseed displacement method [22]. The crumb bread hardness was assessed using texture analyser (Instron 1140). Two bread loaves were cut to obtain 35-mm thick slices. Two slices were taken from the center of each loaf and were used to evaluate crumb hardness. The test was performed at a speed of $50 \mathrm{~mm} \mathrm{~min}^{-1}$ and load cell $500 \mathrm{~N}$. The crumb was pressed by $50 \%$ by aluminium sampler with a diameter $35 \mathrm{~mm}$ at center place of prepared bread slices. Hardness was expressed as the force (in N) required to achieve a predetermined deformation of the crumb breads, and was determined on the basis of the graph (the maximum peak height). The crumb moisture was measured using the oven drying method ( $10 \mathrm{~g}$ of crumb was dried in an oven for $1 \mathrm{~h}$ at $130^{\circ} \mathrm{C}$ ).

\section{Statistical analysis}

All tests were performed in four replicates. The results were statistically analyzed in the Statistica 10 . One-way analysis of variance (ANOVA) was made with significance level $\alpha=0.05$. The homogenous groups were determined by Tukey's test. Besides, and the Pearson's correlation coefficients for relationships between various flour properties were calculated and a statistical differences at $p<0.05$ and $p<0.01$ were considered to be significant. Principal component analysis (PCA), which is a multivariable approach designed for multicorrelated data, was also performed on the whole data set.

\section{Result and discussion}

\section{Flour properties}

The basic quality parameters characterized the rye flour were presented in Table 2 . The protein content ranged from $8.2 \%$ dry mass (dm) (F1) do $11.1 \% \mathrm{dm}(\mathrm{F} 7)$ and the ash content changed from $0.75 \% \mathrm{dm}(\mathrm{F} 1)$ to $1.52 \% \mathrm{dm}(\mathrm{F} 6)$. According to Gleń [23] the rye dough obtained from rye flour with the protein content above $10.5 \% \mathrm{dm}$ shows high plasticity and viscosity, which negatively influence on dough shaping. The flour samples F4 and F7-F10 were characterized by protein content above $10.5 \% \mathrm{dm}$, which can indicate the lower baking quality of these flours. The results showed significant correlations between protein content and ash content
Table 2 Quality parameters of rye flour

\begin{tabular}{lllllll}
\hline Rye flour & PC $(\% \mathrm{dm})$ & AC $(\% \mathrm{sm})$ & FPS $(\%)$ & FN $(\mathrm{s})$ & APV (BU) & WA (\%) \\
\hline F1 & $8.2^{\mathrm{a}} \pm 0.01$ & $0.75^{\mathrm{a}} \pm 0.01$ & $75.3^{\mathrm{j}} \pm 0.1$ & $290^{\mathrm{h}} \pm 6$ & $630^{\mathrm{g}} \pm 7$ & $60.8^{\mathrm{c}} \pm 0.4$ \\
F2 & $9.5^{\mathrm{b}} \pm 0.08$ & $1.38^{\mathrm{d}} \pm 0.01$ & $37.6^{\mathrm{g}} \pm 0.3$ & $212^{\mathrm{c}} \pm 4$ & $370^{\mathrm{c}} \pm 3$ & $58.3^{\mathrm{b}} \pm 0.1$ \\
F3 & $9.4^{\mathrm{b}} \pm 0.06$ & $1.37^{\mathrm{d}} \pm 0.01$ & $35.3^{\mathrm{e}} \pm 0.1$ & $182^{\mathrm{a}} \pm 6$ & $360^{\mathrm{b}} \pm 4$ & $58.4^{\mathrm{b}} \pm 0.1$ \\
F4 & $10.6^{\mathrm{c}} \pm 0.02$ & $1.50^{\mathrm{f}} \pm 0.02$ & $25.2^{\mathrm{a}} \pm 0.1$ & $232^{\mathrm{e}} \pm 3$ & $280^{\mathrm{a}} \pm 7$ & $54.2^{\mathrm{a}} \pm 0.6$ \\
F5 & $9.4^{\mathrm{b}} \pm 0.05$ & $1.34^{\mathrm{c}} \pm 0.01$ & $36.3^{\mathrm{f}} \pm 0.1$ & $187^{\mathrm{a}} \pm 4$ & $350^{\mathrm{b}} \pm 11$ & $58.2^{\mathrm{b}} \pm 0.1$ \\
F6 & $10.5^{\mathrm{bc}} \pm 0.07$ & $1.52^{\mathrm{f}} \pm 0.01$ & $29.4^{\mathrm{c}} \pm 0.1$ & $201^{\mathrm{b}} \pm 4$ & $290^{\mathrm{a}} \pm 7$ & $54.0^{\mathrm{a}} \pm 0.1$ \\
F7 & $11.1^{\mathrm{e}} \pm 0.01$ & $1.24^{\mathrm{b}} \pm 0.01$ & $38.4^{\mathrm{h}} \pm 0.6$ & $239^{\mathrm{e}} \pm 6$ & $460^{\mathrm{d}} \pm 4$ & $63.6^{\mathrm{d}} \pm 0.1$ \\
F8 & $10.6^{\mathrm{c}} \pm 0.03$ & $1.43^{\mathrm{e}} \pm 0.02$ & $40.0^{\mathrm{i}} \pm 0.9$ & $222^{\mathrm{d}} \pm 3$ & $450^{\mathrm{d}} \pm 14$ & $64.8^{\mathrm{e}} \pm 0.3$ \\
F9 & $10.6^{\mathrm{c}} \pm 0.01$ & $1.31^{\mathrm{c}} \pm 0.01$ & $34.3^{\mathrm{d}} \pm 0.1$ & $274^{\mathrm{g}} \pm 6$ & $510^{\mathrm{f}} \pm 7$ & $66.1^{\mathrm{f}} \pm 0.8$ \\
F10 & $10.8^{\mathrm{d}} \pm 0.03$ & $1.32^{\mathrm{c}} \pm 0.02$ & $26.2^{\mathrm{b}} \pm 0.3$ & $254^{\mathrm{f}} \pm 3$ & $480^{\mathrm{e}} \pm 4$ & $66.7^{\mathrm{f}} \pm 0.4$ \\
\hline
\end{tabular}

The values designated by the different letter in the columns of table are statistically significantly different $(\alpha=0.05)$

$P C$ protein content, $A C$ ash content, FPS the mass fraction of flour pass through sieve of $0.95 \mathrm{~mm}, F N$ falling number, $A P V$ amylograph peak viscosity, $W A$ water absorption 
$(r=0.645, p<0.05$, Table 6). It is in agreement with the results of Michalska and Zielińska [24] and Gómeza et al. [25]. The water absorption of flour changed from $54.0 \%$ (F6) to $66.7 \%$ (F10). Obtained flours had different granulometric compositions established by evaluating the pass through the sieve of 95 mesh test. The highest amount of particles below $95 \mu \mathrm{m}$ was found in the flour F1, whereas the coarse flour (the lowest mass fraction of particles above $95 \mu \mathrm{m}$ ) was obtained for F4 sample. The rye flours significantly differ according to the falling number (FN), and amylograph peak viscosity of flour (APV). These parameters are very important for the evaluation of susceptibility of starch on enzyme degradation and starch ability to swelling and gelatinization [26-28]. The results of FN ranged from $183 \mathrm{~s}(\mathrm{~F} 3)$ to $290 \mathrm{~s}$ (F1), whereas the APV changed from to $280 \mathrm{BU}$ (F4) to 630 BU (F1). The results showed significant and positive correlation between the FN and APV ( $r=0.811, p<0.01$, Table 6$)$. Similar correlation was found by the others authors [29, 30].

Table 3 presents the results of pentosans evaluation in the rye flour. The total pentosans content ranged from $7.9 \mathrm{dm}$ (F2) to $9.8 \mathrm{dm}$ (F10). The pentosans content significantly correlated with water absorption of flour $(r=0.698, p<0.05$, Table 6). Similar tendencies were observed by other authors [2, 31-33]. Tokar et al. [34] fund that, the highest influence on ability to bind water by the pentosans has their molecular weight. Increase the molecular weight of pentosans causes increase in water absorption. In this work, flour sample F1 was characterized by similar total pentosans content such as samples F4 and F5 but had statistically higher water absorption. It is caused probably due to differences in molecular weight of pentosans. The highest content of water extractable pentosans $(4.3 \% \mathrm{dm})$ was found in the sample F7 and the lowest $(2.6 \% \mathrm{dm})$ in the flour F5. The water extractable pentosans content significantly correlated with FN and APV

Table 3 The content of pentosans in rye flour

\begin{tabular}{lllll}
\hline Rye flour & TPC $(\% \mathrm{dm})$ & WEP $(\% \mathrm{dm})$ & WUP $(\% \mathrm{dm})$ & $\%$ WEP \\
\hline F1 & $8.5^{\mathrm{b}} \pm 0.07$ & $4.1^{\mathrm{d}} \pm 0.16$ & $4.4^{\mathrm{b}} \pm 0.08$ & $48^{\mathrm{d}} \pm 1$ \\
F2 & $7.9^{\mathrm{a}} \pm 0.22$ & $2.7^{\mathrm{a}} \pm 0.13$ & $5.2^{\mathrm{c}} \pm 0.09$ & $35^{\mathrm{b}} \pm 2$ \\
F3 & $8.4^{\mathrm{b}} \pm 0.08$ & $3.0^{\mathrm{b}} \pm 0.13$ & $5.4^{\mathrm{cd}} \pm 0.05$ & $36^{\mathrm{b}} \pm 1$ \\
F4 & $8.5^{\mathrm{b}} \pm 0.14$ & $3.2^{\mathrm{b}} \pm 0.10$ & $5.3^{\mathrm{c}} \pm 0.04$ & $38^{\mathrm{bc}} \pm 1$ \\
F5 & $8.5^{\mathrm{b}} \pm 0.08$ & $2.6^{\mathrm{a}} \pm 0.11$ & $5.9^{\mathrm{e}} \pm 0.03$ & $31^{\mathrm{a}} \pm 1$ \\
F6 & $9.1^{\mathrm{c}} \pm 0.12$ & $3.6^{\mathrm{c}} \pm 0.14$ & $5.5^{\mathrm{d}} \pm 0.02$ & $40^{\mathrm{c}} \pm 1$ \\
F7 & $9.3^{\mathrm{cd}} \pm 0.07$ & $4.3^{\mathrm{d}} \pm 0.11$ & $4.0^{\mathrm{a}} \pm 0.09$ & $46^{\mathrm{e}} \pm 1$ \\
F8 & $9.4^{\mathrm{d}} \pm 0.11$ & $3.3^{\mathrm{b}} \pm 0.13$ & $6.1^{\mathrm{e}} \pm 0.24$ & $35^{\mathrm{b}} \pm 2$ \\
F9 & $9.5^{\mathrm{d}} \pm 0.18$ & $4.1^{\mathrm{d}} \pm 0.17$ & $5.5^{\mathrm{d}} \pm 0.06$ & $43^{\mathrm{d}} \pm 1$ \\
F10 & $9.8^{\mathrm{e}} \pm 0.14$ & $3.7^{\mathrm{c}} \pm 0.08$ & $6.1^{\mathrm{e}} \pm 0.05$ & $38^{\mathrm{bc}} \pm 4$ \\
\hline
\end{tabular}

The values designated by the different letter in the columns of table are statistically significantly different $(\alpha=0.05)$

$T P C$ total pentosans content, WEP water extractable pentosans content, $W U P$ water unextractable pentosans content, $\% W E P$ percent of pentosans soluble in water from the total of pentosans $(r=0.759, p<0.05$ and $r=0.632, p<0.05$, respectively, Table 6). The water unextractable pentosans content ranged from $4.4 \% \mathrm{dm}(\mathrm{F} 1)$ to $6.1 \% \mathrm{dm}(\mathrm{F} 8)$ and was positively correlated with FPS $(r=-0.661, p<0.05$, Table 6$)$. \%WEP was in the range from $31 \%$ (F5) to $48 \%$ (F1) and was positively related with FN and APV $[r=0.745, p<0.05$ and $r=0.619$, $p<0.05$, respectively (Table 6)].

\section{Results of swelling curve test}

The results of parameters obtained on the basis of swelling curves were significantly different between individual flour samples (Table 4). The changes of these parameters are related to the changes during dough mixing, fermentation and during the first phase of baking. Rasmussen et al. [35] showed that the optimal conditions for enzymes which degradation of pentosans is $\mathrm{pH}$ in the range 3.8-5.3 and temperature $40{ }^{\circ} \mathrm{C}$. Therefore, the conditions during swelling curve test are optimal for enzymatic degradation of pentosans. The initial viscosity (VA), which reflect the amount of water-binding material present in rye flour, ranged from $175 \mathrm{BU}(\mathrm{F} 4)$ to $845 \mathrm{BU}$ (F9) while the viscosity when the sample reaching temperature $42^{\circ} \mathrm{C}(\mathrm{VB})$ changed from 175 BU (F4) to 675 BU (F9). The final viscosity (VC), which depends on the amount of swelling substances, the swelling or hydration properties of these substances and the degree of enzymatic degradation during test, was in the range from $165 \mathrm{BU}(\mathrm{F} 2)$ to $355 \mathrm{BU}$ (samples F7, F9, F10). The results showed significant correlations between all viscosity parameters obtained on the basis of swelling curve and FN (Table 6). Our results clearly show that the values of viscosity parameters obtained on the basis of swelling curve were positively and significantly correlated with the water extractable pentosans content and their share in the total pentosans

Table 4 The swelling curves parameters

\begin{tabular}{lllll}
\hline Rye flour & VA (BU) & VB (BU) & VC (BU) & $\operatorname{logVB}-\operatorname{logVC}$ \\
\hline F1 & $685^{\mathrm{g}} \pm 21$ & $560^{\mathrm{f}} \pm 18$ & $280^{\mathrm{e}} \pm 25$ & $301^{\mathrm{f}} \pm 25$ \\
F2 & $205^{\mathrm{bc}} \pm 7$ & $190^{\mathrm{b}} \pm 7$ & $165^{\mathrm{a}} \pm 7$ & $61^{\mathrm{c}} \pm 35$ \\
F3 & $195^{\mathrm{b}} \pm 4$ & $190^{\mathrm{b}} \pm 7$ & $185^{\mathrm{b}} \pm 7$ & $12^{\mathrm{b}} \pm 1$ \\
F4 & $175^{\mathrm{a}} \pm 7$ & $175^{\mathrm{a}} \pm 7$ & $215^{\mathrm{c}} \pm 7$ & $-89^{\mathrm{a}} \pm 3$ \\
F5 & $215^{\mathrm{c}} \pm 7$ & $200^{\mathrm{c}} \pm 3$ & $175^{\mathrm{ab}} \pm 11$ & $58^{\mathrm{c}} \pm 26$ \\
F6 & $280^{\mathrm{d}} \pm 14$ & $290^{\mathrm{d}} \pm 7$ & $280^{\mathrm{e}} \pm 7$ & $15^{\mathrm{b}} \pm 2$ \\
F7 & $510^{\mathrm{e}} \pm 21$ & $505^{\mathrm{e}} \pm 18$ & $355^{\mathrm{f}} \pm 21$ & $153^{\mathrm{d}} \pm 11$ \\
F8 & $280^{\mathrm{d}} \pm 11$ & $275^{\mathrm{d}} \pm 14$ & $245^{\mathrm{d}} \pm 21$ & $50^{\mathrm{c}} \pm 15$ \\
F9 & $845^{\mathrm{h}} \pm 14$ & $675^{\mathrm{g}} \pm 25$ & $355^{\mathrm{f}} \pm 18$ & $279^{\mathrm{f}} \pm 6$ \\
F10 & $630^{\mathrm{f}} \pm 18$ & $565^{\mathrm{f}} \pm 21$ & $355^{\mathrm{f}} \pm 28$ & $202^{\mathrm{e}} \pm 18$ \\
\hline
\end{tabular}

The values designated by the different letter in the columns of table are statistically significantly different $(\alpha=0.05)$

$V A$ initial viscosity at $30^{\circ} \mathrm{C}, V B$ viscosity when the sample reaching $42{ }^{\circ} \mathrm{C}, V C$ viscosity after holding at $42{ }^{\circ} \mathrm{C}$ for $30 \mathrm{~min}, \log V B-\log V C$ logarithmic decrease of viscosity at $42{ }^{\circ} \mathrm{C}$ 
content (Table 6). The most of tested flour samples were characterized by the decrease of viscosity after heating the samples from 30 to $42{ }^{\circ} \mathrm{C}$. It is caused by the degradation of water extractable pentosans up to the compounds with lower molecular weight [10]. Only in the case of F6 sample the slight increase of viscosity was observed after heating this sample from 30 to $42{ }^{\circ} \mathrm{C}$. It is probably caused by the transformation of water unextractable pentosans up to soluble forms up to the moment when the degradation of extractable pentosans caused a decrease of viscosity [12]. The values of logarithmic decrease of viscosity during holding a slurry at $42{ }^{\circ} \mathrm{C}$, ranged from $-89(\mathrm{~F} 4)$ to $301(\mathrm{~F} 1)$. This parameter informs indirectly about activity of enzymes hydrolyzed pentosans (EHP). The negative value of this parameter for F4 sample indicates about very low activity of EHP. In the case of very low EHP transformation of water unextractable pentosans into soluble form during baking is very limited. It causes that starch has low level of water for gelatinization and that negatively influences on bread properties [36]. The optimum level of pentosans depolimerization exchange the dough elasticity, which increase the ability of dough to keep carbon dioxide and obtained bread is characterized by increased volume, and softer crumb. To excessive hydrolysis of pentosans causes a decrease of dough ability to keep the carbon dioxide and it has negative influence on bread volume $[37,38]$. The results showed significant relation between the logarithmic decrease of viscosity and the amylograph peak viscosity and FN $(r=0.921, p<0.01$ and $r=0.792, p<0.01$, respectively, Table 6).

\section{Bread properties}

Table 5 presents the results of dough yield and quality parameters of bread. The dough yield changed from $168 \%$ (F2 and F5) to $176 \%$ (F10). This parameter was positively correlated with water absorption of flour and with the all viscosity parameters obtained on the basis of swelling curve (Table 6). The bread volume changed from $170 \mathrm{~cm}^{3} / 100 \mathrm{~g}$ (F6) to $249 \mathrm{~cm}^{3} / 100 \mathrm{~g}(\mathrm{~F} 1)$. Generally, the breads with the lowest volume were obtained from flour with high protein content, more coarse flour, higher ash content, low amylograph peak viscosity and low logarithmic decrease of viscosity. The bread yield ranged from $135 \%$ (F2) to $149 \%$ (F7). The bread yield was positively correlated with viscosity parameters: VA and VC $(r=0.649, p<0.05, r=0.819$, $p<0.01$, respectively, Table 7). Beside this, the total pentosans content and the water extractable pentosans content positively influenced on bread volume $(r=0.797, p<0.01$, and $r=0.758, p<0.05$, respectively) (Table 7).

The crumb hardness in one of the most important bread texture parameters [2]. The lowest hardness after 1 and 4 days bread storage was found in the bread obtained from flour F1 (19.1 and 28.4 N, respectively), whereas the highest values of this parameter were found for bread crumb from $\mathrm{F} 4$ sample (89.5 and $160.4 \mathrm{~N}$, respectively). Most importantly, the logarithmic decrease of viscosity was negatively correlated with crumb bread hardness after 1 and 4 days storage of bread ( $r=-0.802, r=-0.789$, respectively, Table 7). The crumb moisture changed from $44.0 \%$ (F5) to $50.4 \%$ (F6) and was positively correlated with water extractable pentosans and total pentosans content $(r=0.761, p<0.05$ and $r=0.793, p<0.01$, respectively, Table 7). Beside this, bread moisture content was positively correlated with VA and VC parameters obtained on the basis of swelling curve $(r=0.674, p<0.05$ and $r=0.805, p<0.01$, respectively, Table 7).

The results of principal component analysis (PCA) were presented on Fig. 2. Using PCA, it was possible to reduce the dimension of the raw data and identify several correlations between various flour properties. The properties whose
Table 5 Yield of dough and quality parameters of obtained breads

\begin{tabular}{|c|c|c|c|c|c|c|c|}
\hline Rye flour & YD (\%) & $\mathrm{BV}\left(\mathrm{cm}^{3} / 100 \mathrm{~g}\right)$ & YB (\%) & $\mathrm{CH} 1(\mathrm{~N})$ & $\mathrm{CH} 4(\mathrm{~N})$ & $\mathrm{HI}(\mathrm{N})$ & $\mathrm{CM}(\%)$ \\
\hline $\mathrm{F} 1$ & 173 & $249^{\mathrm{e}} \pm 8$ & $147^{\mathrm{de}} \pm 1$ & $19.1^{\mathrm{a}} \pm 1.0$ & $28.4^{\mathrm{a}} \pm 0.3$ & $9.3^{\mathrm{a}} \pm 1.3$ & $49.2^{\mathrm{cd}} \pm 0.6$ \\
\hline F2 & 168 & $199^{d} \pm 3$ & $135^{\mathrm{a}} \pm 1$ & $43.4^{\mathrm{e}} \pm 5.4$ & $83.4^{\mathrm{e}} \pm 1.6$ & $40.0^{\mathrm{h}} \pm 6.9$ & $45.2^{\mathrm{ab}} \pm 0.6$ \\
\hline F3 & 173 & $179^{\mathrm{b}} \pm 8$ & $143^{\mathrm{b}} \pm 0$ & $39.2^{\mathrm{d}} \pm 1.0$ & $60.3^{\mathrm{d}} \pm 1.1$ & $21.1^{\mathrm{d}} \pm 0.1$ & $48.4^{\mathrm{c}} \pm 0.6$ \\
\hline F4 & 170 & $171^{\mathrm{a}} \pm 1$ & $138^{\mathrm{b}} \pm 1$ & $89.5^{\mathrm{h}} \pm 1.8$ & $160.4^{\mathrm{g}} \pm 0.6$ & $70.9^{\mathrm{i}} \pm 1.3$ & $46.4^{\mathrm{b}} \pm 0.9$ \\
\hline F5 & 168 & $194^{\mathrm{e}} \pm 7$ & $141^{\mathrm{b}} \pm 1$ & $52.5^{\mathrm{f}} \pm 1.1$ & $89.3^{\mathrm{f}} \pm 2.0$ & $36.8^{\mathrm{g}} \pm 3.1$ & $44.0^{\mathrm{a}} \pm 0.7$ \\
\hline F6 & 170 & $170^{\mathrm{ab}} \pm 4$ & $145^{\mathrm{cd}} \pm 1$ & $60.8^{\mathrm{g}} \pm 2.5$ & $89.8^{\mathrm{f}} \pm 2.1$ & $29.0^{\mathrm{f}} \pm 0.4$ & $50.4^{\mathrm{e}} \pm 0.2$ \\
\hline F7 & 172 & $176^{\mathrm{b}} \pm 4$ & $149^{\mathrm{e}} \pm 1$ & $32.2^{\mathrm{b}} \pm 0.1$ & $43.9^{\mathrm{b}} \pm 1.5$ & $11.7^{\mathrm{b}} \pm 0.6$ & $49.5^{\mathrm{d}} \pm 0.1$ \\
\hline F8 & 174 & $186^{\mathrm{c}} \pm 1$ & $143^{\mathrm{b}} \pm 1$ & $45.4^{\mathrm{e}} \pm 0.6$ & $59.6^{\mathrm{d}} \pm 0.8$ & $14.2^{c} \pm 0.3$ & $49.5^{\mathrm{d}} \pm 0.2$ \\
\hline F9 & 174 & $185^{\mathrm{c}} \pm 4$ & $144^{\mathrm{c}} \pm 1$ & $40.0^{\mathrm{d}} \pm 1.1$ & $53.7^{\mathrm{c}} \pm 0.8$ & $13.7^{\mathrm{c}} \pm 0.3$ & $50.3^{\mathrm{e}} \pm 0.2$ \\
\hline F10 & 176 & $193^{\mathrm{d}} \pm 4$ & $146^{\mathrm{d}} \pm 1$ & $35.9^{c} \pm 0.4$ & $59.4^{\mathrm{d}} \pm 0.8$ & $23.5^{\mathrm{e}} \pm 0.4$ & $50.2^{\mathrm{e}} \pm 0.1$ \\
\hline
\end{tabular}

The values designated by the different letter in the columns of table are statistically significantly different $(\alpha=0.05)$

$Y D$ dough yield, $B V$ specific bread volume, $Y B$ yield of bread, $C H 1$ crumb bread hardness 1 day after baking, $\mathrm{CH} 4$ crumb bread hardness 4 days after baking, $H I$ hardness increase after 3 days storage of bread, $C M$ crumb moisture 


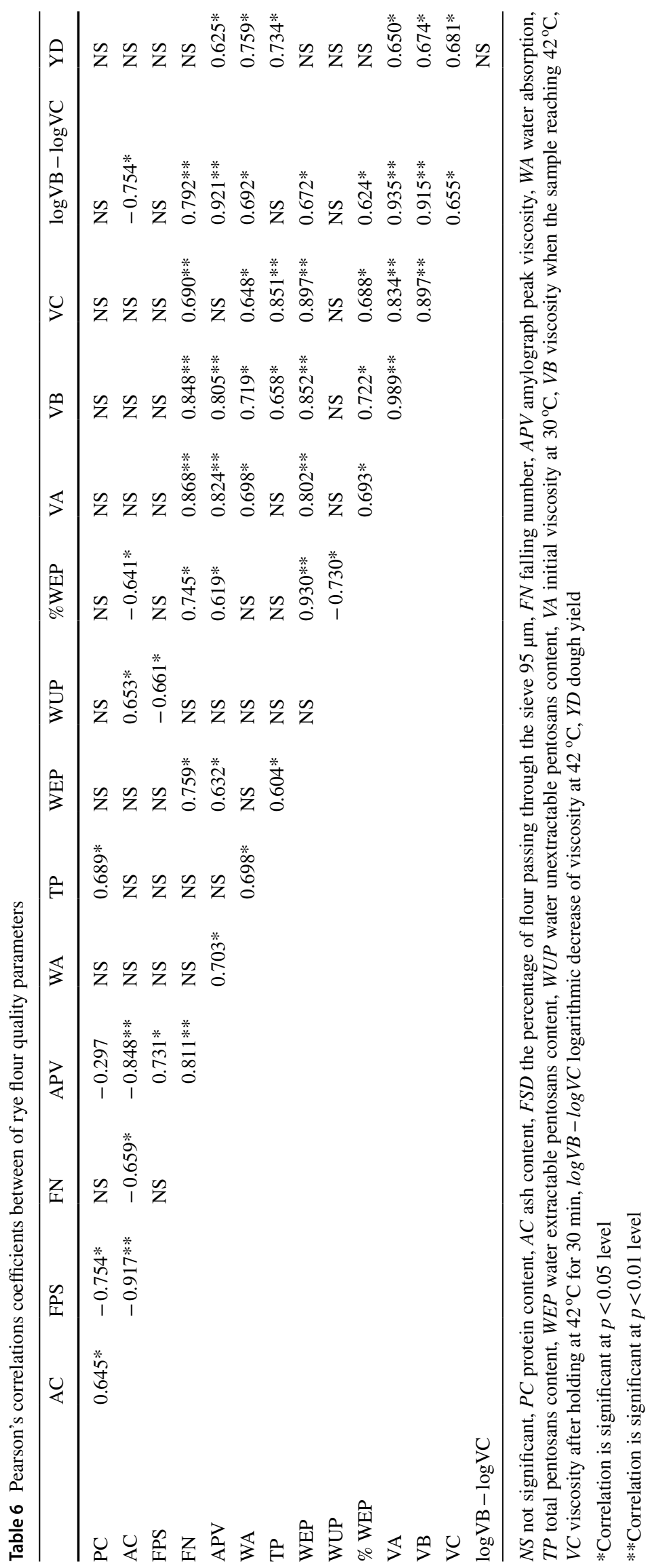


Table 7 Pearson's correlations coefficients between of rye flour and bread properties

\begin{tabular}{|c|c|c|c|c|c|c|}
\hline & $\mathrm{BV}$ & YB & $\mathrm{CH} 1$ & $\mathrm{CH} 4$ & HI & $\mathrm{CM}$ \\
\hline $\mathrm{PC}$ & $-0.789 * *$ & NS & NS & NS & NS & NS \\
\hline $\mathrm{AC}$ & $-0.903 * *$ & NS & $0.724 *$ & $0.644^{*}$ & NS & NS \\
\hline FPS & $0.896^{* *}$ & NS & $-0.639 *$ & NS & NS & NS \\
\hline FN & NS & NS & NS & NS & NS & NS \\
\hline APV & $0.746^{*}$ & NS & $-0,824 * *$ & $-0.667 *$ & $-0.808 * *$ & NS \\
\hline WA & NS & NS & $-0.627 *$ & NS & $-0.669 * *$ & NS \\
\hline $\mathrm{TP}$ & NS & $0.797 * *$ & NS & NS & NS & $0.793 * *$ \\
\hline WEP & NS & $0.758^{*}$ & NS & NS & NS & $0.761 *$ \\
\hline WUP & NS & NS & NS & NS & NS & NS \\
\hline$\% \mathrm{WEP}$ & NS & NS & NS & NS & NS & $0.615^{*}$ \\
\hline VA & NS & NS & NS & NS & NS & NS \\
\hline VB & NS & $0.649 *$ & NS & $-0.640^{*}$ & $-0.639 *$ & $0.674 *$ \\
\hline $\mathrm{VC}$ & NS & $0.819 * *$ & NS & NS & NS & $0.805 * *$ \\
\hline $\log \mathrm{VB}-\log \mathrm{VC}$ & $0.637 *$ & NS & $-0.802 * *$ & $-0.789 * *$ & $-0.727 *$ & NS \\
\hline
\end{tabular}

$N S$ not significant, $P C$ protein content, $A C$ ash content, $F S D$ the percentage of flour passing through the sieve $95 \mu \mathrm{m}, F N$ falling number, $A P V$ maximum amylograph peak viscosity, $W A$ water absorption, $T P$ total pentosans content, WEP water extractable pentosans content, $W U P$ water unextractable pentosans content, $V A$ initial viscosity at $30{ }^{\circ} \mathrm{C}, V B$ viscosity when the sample reaching $42{ }^{\circ} \mathrm{C}, V C$ viscosity after holding at $42{ }^{\circ} \mathrm{C}$ for $30 \mathrm{~min}, \log V B-\log V C$ logarithmic decrease of viscosity at $42{ }^{\circ} \mathrm{C}, B V$ specific bread volume, $Y B$ yield of bread, $\mathrm{CH} 1$ crumb bread hardness 1 day after baking, $\mathrm{CH} 4$ crumb bread hardness 4 days after baking, $H I$ hardness increase after 3 days storage of bread, $C M$ crumb moisture

*Correlation is significant at $p<0.05$ level

**Correlation is significant at $p<0.01$ level

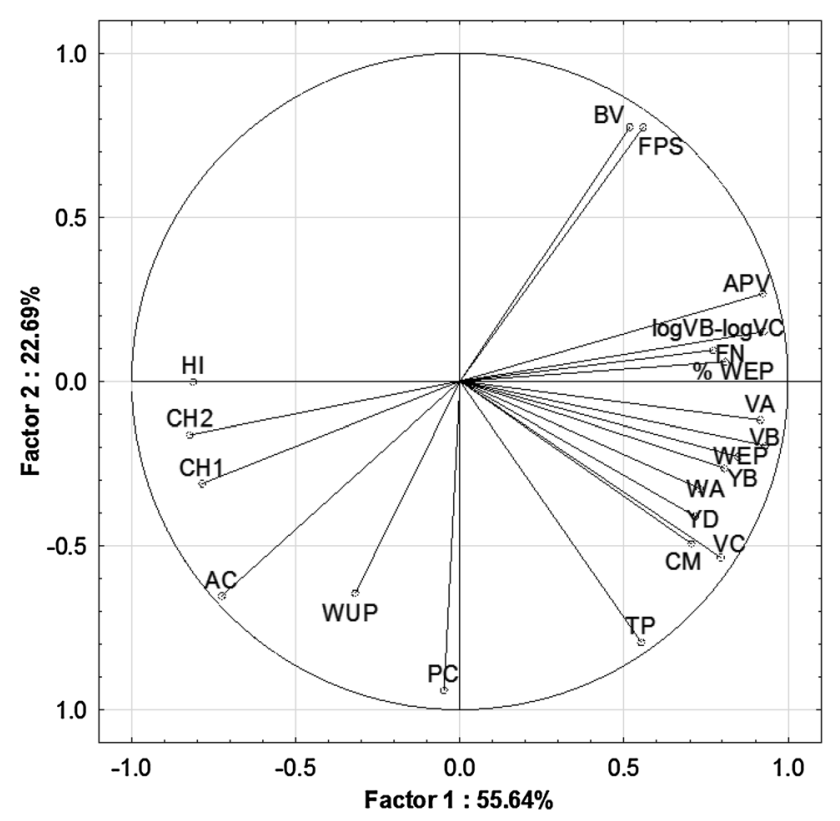

Fig. 2 Principal component analysis: loading plot of PC1 and PC2 for the evaluated parameters of rye flour

curves line are close to each other on the plot are positively correlated while those whose curves run is opposite are negatively correlated. Variables located in the perpendicular directions along the PC axis are independent of each other. The first and the second component described 55.64 and $22.69 \%$ of the variance, respectively. Together, the first two components represent $78.33 \%$ of the total variability. The first principal component was positively related to the all parameters obtained from swelling curve: AV, FN, WA, WEP, YD, CM and was negatively related to AC and crumb hardness. The second principal component was positively correlated with FSD, TP, BV and negatively correlated with PC. Figure 2 shows that VA and VB were strongly correlated with WEP, FN and WA. Beside this, the values of VC positively influenced on CM, YB, YD, WA, WEP and TP. Whereas the logarithmic decrease of viscosity positively correlated with APV, FN and \%WEP, while negatively correlated with crumb hardness and hardness increase during storage of bread.

\section{Conclusions}

The test of swelling curve is simple and adequate method for the evaluation of the baking quality of rye flour. The parameters obtained on the basis of swelling curve especially correlated with enzymes activity, the content of water extractable pentosans and bread properties. The highest correlation were found between parameters VA and VB and the falling numbers. Most importantly, the viscosity parameters significantly correlated with bread yield, volume and crumb 
hardness. Especially the swelling curve change in viscosity was negatively correlated with bread hardness. In summary, the swelling curve test can be used as useful tool for the evaluation of baking quality of rye flour.

\section{Compliance with ethical standards}

Conflict of Interest The authors declare that there is no conflict of interest regarding the publication of this article.

Open Access This article is distributed under the terms of the Creative Commons Attribution 4.0 International License (http://creativecommons.org/licenses/by/4.0/), which permits unrestricted use, distribution, and reproduction in any medium, provided you give appropriate credit to the original author(s) and the source, provide a link to the Creative Commons license, and indicate if changes were made.

\section{References}

1. Bondia-Pons I, Aura A, Vuorela S, Kolehmainen M, Mykkänen H, Poutanen K (2009) Rye phenolics in nutrition and health. J Cereal Sci 49(3):323-336

2. Buksa K, Nowotka A, Praznik W, Gambuś H, Ziobro R, Krawontka J (2010) The role of pentosans and starch in baking of wholemeal rye bread. Food Res Int 43:2045-2051

3. Gräber S (1999) The influence of enzyme treatment on the rheology of rye dough. Food/Nahrung 43(4):249-252

4. Izydorczyk MS, Biliaderis CG (1995) Cereal arabinoxylans: advances in structure and physicochemical properties. Carbohydr Polym 28:33-48

5. Saeed F, Pasha I, Anjum FM, Sultan JI (2011) Water-extractable arabinoxylans content in milling fractions of spring wheats. $\mathrm{J}$ Food Sci Nut 9(1):43-48

6. Jaekel LZ, Silva CB, Steel C, Change YK (2012) Influence of xylanase addition on the charakteristics of loaf bread prepared with white flour or whole grain wheat flour. Ciencia Technol Alime 32(4):844-849

7. Zhang XG, Xue DW, Zhang GP (2013) Genotypic and environmental variations of arabinoxylans content and endoxylanase activity in barley grains. J Int Agric 12(8):1489-1494

8. Weipert D (1997) Processing performance of rye as compared to wheat. Cereal Food World 42(8):706-712

9. Cleemput G, Booij C, Hessing M, Gruppen H, Delcour JA (1997) Solubilisation and changes in molecular weight distribution of arabinoxylans and protein in wheat flour during bread-making and the effect of endogenous arabinoxylans hydrolyzing enzymes. J Cereal Sci 26:55-66

10. Courtin CM. Gelders GG, Delcour JA (2001) Use of two endoxylanases with different substrate selectivity for understanding arabinoxylans functionality in wheat flour breadmaking. Cereal Chem 78(5):564-571

11. Li W, Hu H, Wang Q, Brennan CS (2013) Molecular features of wheat endosperm arabinoxylan inclusion in functional bread. Foods 2:225-237

12. Courtin CM, Delcour JA (2002) Arabinoxylans and endoxylanases in wheat flour bread making. J Cereal Sci 35:225-243

13. Rouau X, Moreau D (1993) Modification of some physicochemical properties of wheat flour pentosans by an enzyme complex recommended for baking. Cereal Chem 70(6):626-632

14. Martinez-Anaya MA, Jimenez T (1997) Functionality of enzymes that hydrolyse starch and non-starch polysaccharide in breadmaking. Eur Food Res Technol 205(3):209-214
15. Bushuk W (2001) Rye: production, chemistry and technology, 2nd edn. AACC, St. Paul

16. Autio K, Flander L, Heinonen R, Kinnunen A (1999) Comparison off small and large deformation measurements of whole meal rye doughs. Cereal Chem 76(6):912-914

17. Hansen HB, Andreasen MF, Nielsen MM (2002) Changes in dietary fiber, phenolic acids and activity of endogenous enzymes during rye bread-making. Eur Food Res Technol 214:33-42

18. Salmenkallio-Marttila M, Hovinen S (2005) Enzyme activities, dietary fibre components and rheological properties of wholemeal flours from rye cultivars grown in Finland. J Sci Food Agric $85: 1350-1356$

19. ICC - standard methods: 104/1 (1990) Determination of ash in cereals and cereal products, 105/2 (1994), Determination of crude protein in cereals and cereal products for food and for feed, 107/1 (1995) Determination of the "falling number" according to Hagberg - as a measure of the degree of alpha-amylase activity in grain and flour, 115/1 (1992) Method for using the Brabender farinograph, 126/1 (1992) Method for using the Brabender amylograph, Vienna, Austria: International Association for Cereal Science and Technology

20. Hashimoto S, Shogren MD, Pomeranz Y (1987) Cereal pentosans. their estimation and significance. I. Pentosans in wheat and milled wheat products. Cereal Chem 64(1):30-34

21. Drews E (1971) Quellkurven von Roggenmahlprodukten. Die Muehle 108(49):723-724

22. Rożyło R, Dziki D, Gawlik-Dziki U, Cacak-Pietrzak G, Miś A, Rudy S (2015) Physical properties of gluten-free bread caused by water addition. Int Agrophys 29(3):353-364

23. Gleń A (2003) Technological value of rye grain and the selection of varieties and nitrogen dose. Przegl Zboż-Młyn 7:27-29 (in Polish)

24. Michalska A, Zieliński H (2006) Effect of flour extration rate on bioactive compounds content of two rye varieties. Pol J Food Nutr Sci 15/56(3):297-303

25. Gómez M, Pardo J, Oliete B, Caballero P (2009) Effect of milling process on quality characteristics of rye flour. J Sci Food Agric $89: 470-476$

26. Banu I (2006) The evaluation of the quality rye flours on the basis of the biochemical and rheological indices. J Agroaliment Process Technol 12(2):291-298

27. Beck M, Jekle M, Selmair PL, Koehler P, Becker T (2011) Rheological properties and baking performance of rye dough as affected by transglutaminase. J Cereal Sci 54:29-36

28. Poutanen K, Katina K, Heiniö RL (2014) Rye. In: Zhou W (ed) Bakery products science and technology, 2nd edn. Wiley-Blackwell, Hoboken, pp 75-87

29. Repeckinen A, Eliasson AC, Juodeikiene G, Gunnarsson E (2001) Predicting baking performance from rheological and adhesive properties of rye meal suspensions during heating. Cereal Chem 78(2):193-199

30. Brummer JM (2003) Problems with the characterization of rye for bread production in Germany. In: Juodeikiene G (ed) Proceedings of Conference 1st Baltic Conference on Rye in the EU Context. ICC, Kaunas University of Technology, pp 79-96

31. Härkönen H, Lehtinen P, Suortti T, Parkkonen T, Siika-aho M, Poutanen K (1994) The effect of a xylanase and a $\beta$-glucanase from Trichoderma reesei on the non-starch polysaccharides of whole meal rye slurry. J Cereal Sci 21:173-183

32. Banu I (2007) Baking quality of rye flour. Bull USAMV-CN 63:488-492

33. Callejo MJ, Bujeda C, Rodriguez G, Chaya C (2009) Alveoconsistograph evaluation of rheological properties of rye doughs. Span J Agric Res 7(3):638-644

34. Tokàr M, Buksa K, Gambuś H, Bojňanská E (2012) Molecular properties of selected polysaccharides determined by sec 
chromatography and their impact on water absorption of wheat flour. Potravinárstvo 6(1):42-44

35. Rasmussen CV, Hansen HB, Hansen A, Larsen LM (2001) PH, temperature and time-dependent activities of endogenous endo$\beta$-D-xylanase, $\beta$-D-xylosidase and $\alpha$-L-arabinofuranosidase in extracts from underminated rye (Secale cereal L.) grain. J Cereal Sci 34:49-60

36. Dornez E, Gebruers K, Delcour JA, Courtin CM (2009) Grainassociated xynalases: occurrence, variability, and implication for cereal processing. Trends Food Sci Tech 20:495-510
37. Butt MS, Tahir-Nadeem M, Ahmad Z, Sultan MT (2008) Xylanases and their applications in baking industry. Food Technol Biotech 46(1):22-31

38. Cyran MR, Dynkowska WM (2014) Mode of endosperm and wholemeal arabinoxylans solubilisation during rye breadmaking: genotypic diversity in level, substitution degree and macromolecular characteristics. Food Chem 145:356-364 